\title{
Ultrastructure of oogenesis in imposex females of Babylonia areolata (Caenogastropoda: Buccinidae)
}

\author{
C. Muenpo $\cdot$ J. Suwanjarat $\cdot$ W. Klepal
}

Received: 29 March 2010/Revised: 24 August 2010/Accepted: 8 September 2010/Published online: 19 September 2010

(C) Springer-Verlag and AWI 2010

\begin{abstract}
During a tributyltin (TBT)-exposure experiment, the ultrastructural features of oogenesis have been examined in TBT-induced imposex females of Babylonia areolata and compared with those of the normal female. The results obtained from such experiment demonstrates that $B$. areolata exhibits a low to moderate intensity of imposex because all VDSI values are never higher than 3 . Ultrastructures of germ cell development including oogonia, pre-vitellogenic, early vitellogenic, late vitellogenic and mature oocytes show that oogenesis in imposex female is similar to that of normal females except for the presence of numerous lipid droplets in the cytoplasm of the oocytes and the follicle cells in imposex females, indicating the degeneration of their oocytes. Vitellogenesis in B. areolata involves both auto- and heterosynthetic processes that resemble those of the basal gastropods and the pulmonates. In addition, the presence of cortical granules and microvilli are unique structures of this species.
\end{abstract}

\section{Keywords Babylonia areolata Buccinidae Imposex .} Oogenesis

Communicated by H.-D. Franke.

C. Muenpo $\cdot$ J. Suwanjarat $(\bowtie)$

Department of Biology, Faculty of Science,

Prince of Songkla University, Hat-Yai 90112, Thailand

e-mail: jintamas.s@psu.ac.th

W. Klepal

Department of Cell Imaging and Ultrastructure Research,

Faculty of Life Science, University of Vienna, Vienna, Austria

\section{Introduction}

The spotted babylon, Babylonia areolata, of the family Buccinidae is economically one of the most important marine gastropods for human consumption (Kritsanapuntu et al. 2009) and is found along coastal areas of many Asian countries (Altena and Van Regteren Gittenberger 1981). Due to the high commercial value of this species, many aspects of B. areolata biology related to its toxicology (Supanopas et al. 2005), nutrition (Xu et al. 2006), breeding technology (Kritsanapuntu et al. 2007) and reproduction (Suwanjarat et al. 2008) have been extensively studied. In the Gulf of Thailand, B. areolata inhabits shallow water between 5 and $20 \mathrm{~m}$ depth on sandy and muddy sea bottoms. This region has been reported to have a high contamination of a toxic compound, tributyltin (TBT) (Kan-atireklap et al. 1997; Harino et al. 2006) that has been used worldwide as a biocide in antifouling paints for ship and boat hulls. Consequently, B. areolata, like various kinds of meso-and neogastropods living in the TBT-contaminated areas in the Gulf of Thailand, becomes imposex, a phenomenon that male sexual organs (penis and vas deferens) are developed onto females (Smith 1971), in response to TBT (Swennen et al. 1997, 2009). Imposex has been occurred in more than 160 species in 60 genera of marine gastropods (deFur et al. 1999) in the TBT-contaminated seawater. However, such filed surveys give no information about imposex development and expression in B. areolata; particularly an effect of TBT on a reproduction of this species is still unknown and needs to be clarified.

The effects of TBT on an occurrence of imposex vary depending on species as in some cases, this condition does not impair reproduction (Amor et al. 2004; Cheng and Liu 2004), while in some others, it causes the imposex female to have reproductive failure and finally leads to a 
population decline and even local extinction (Oehlmann et al. 1996; Horiguchi et al. 2006).

Histologically, apart from having the negative effects on oogenesis (Gibbs et al. 1988; Oehlmann et al. 1996; Horiguchi et al. 2002), TBT also induces spermatogenesis in the ovaries of imposex females (Horiguchi et al. 2002, 2006). However, despite a report of extensive oocyte degeneration in Hexaplex trunculus (Axiak et al. 2003), information on the effect of TBT on oogenesis in imposex females at the ultrastructural level is limited. In this study, a TBT-exposure experiment is conducted to determine the imposex development and intensity in B. areolata in laboratory. Furthermore, the ultrastructural features of oogenesis in imposex females of $B$. areolata have been investigated and compared with those of normal females. For this purpose, an exact process of vitellogenesis in B. areolata is detailed in order to provide additional information for the classification of germ cells that is helpful in assessing gastropod phylogeny and may contribute to the understanding of the relationships of B. areolata to other gastropod species.

\section{Materials and methods}

\section{TBT-induced imposex in laboratory}

Mature specimens of $B$. areolata (size larger than $30 \mathrm{~mm}$ in shell length) used in this study were obtained from the marine laboratory breeding stock at the Aquatic Animal Hatchery and Research Unit, Prince of Songkla University, Pattani campus. TBT-exposure experiment was performed as $48 \mathrm{~h}$ semi-static renewal system in 100-1 aquaria, provided with air filter and natural seawater, and three replicate groups of 70 sexually mature females and 15 males each were exposed to different nominal aqueous concentrations of TBT (1, 10, 50, 100 and $500 \mathrm{ng}$ as $\mathrm{Sn} / \mathrm{l})$ for 6-month period. Additionally, two control groups were run in parallel (water only and glacial acetic acid in water). Stock solutions of TBT were made by dissolving TBT chloride of $>96 \%$ purity (purchased from Aldrich Chemical Co.) into glacial acetic acid. The test solutions of TBT used in the experiment were prepared through a serial dilution with a freshly prepared stock solution in seawater. The final carrier solvent concentration was never higher than $0.001 \%$ in all treatments (except control with water only). The test was conducted under constant conditions regarding temperature and 12-h light/12-h dark cycles.

Water parameters including $\mathrm{pH}$, temperature and salinity were measured once every 2 weeks for each replicate.

Thirty females and five males from every exposure group were analyzed at monthly intervals. The animals were narcotized using $7 \% \mathrm{MgCl}_{2}$ in distilled water, and the penis length in males and imposex females was measured to the nearest $0.1 \mathrm{~mm}$ under a stereo-dissecting microscope using ocular meter with eyepiece. The imposex development was classified into six stages based on the scheme proposed by Stroben et al. (1992a), and the imposex stages of individual females were recorded. In order to determine imposex intensity, the following indices were used: (1) Vas deferens sequence index (VDSI), calculated as the mean value of all imposex stages in a sample and (2) the average female penis length (FPL) of a sample.

\section{Ultrastructural investigation}

According to the criteria classifying the imposex development, every female at the stage $5(n=10)$ obtained from above experiment were collected for electron microscopical studies. Their ovaries and those of normal females were removed, cut into small pieces and prefixed in cold $\left(4^{\circ} \mathrm{C}\right) 2.5 \%$ glutaraldehyde in $0.1 \mathrm{M}$ phosphate buffer, $\mathrm{pH} 7.4$ for $24 \mathrm{~h}$. They were then rinsed for $10 \mathrm{~min}$ in 3 changes of buffer and postfixed in $1 \% \mathrm{OsO}_{4}$ in $0.1 \mathrm{M}$ phosphate buffer, $\mathrm{pH} 7.4$ for $1 \mathrm{~h}$ at room temperature. After fixation, the tissue was dehydrated in a graded series of ethanol up to $100 \%$ and with an intermedium step of propylene oxide. The samples were embedded in Epon 812 . Semi-thin and ultrathin sections were cut with glass knives on a Reichert-Jung Ultracut E ultramicrotome at the Department of Cell Imaging and Ultrastructure Research, Faculty of Life Sciences, University of Vienna, Austria. Semi-thin sections were stained in $0.1 \%$ toluidine blue and observed with a light microscope. Ultrathin sections were stained in $2 \%$ uranyl acetate $(30 \mathrm{~min})$ and $0.5 \%$ lead citrate (5 min) and viewed with a Zeiss EM 902.

\section{Results}

Imposex development and intensity

\section{Imposex development}

Imposex expressions in prosobranchs are generally described by an evolutionary scheme and classified into six stages (1-6), most of which could have multiple types $(a-c)$ (Fig. 1). Five stages of imposex development in $B$. areolata induced by TBT during the exposure experiment were observed with two types (a and c) in stage 1; three types ( $a, b$ and $c$ ) in stages 2 and 3; and only one type in stages 4 and 5 (b) (Fig. 1). Comparing to a normal female (always referred to stage 0 ) that does not have any male characteristics, the morphological expression of imposex in $B$. areolata advances continuously from stage 1 that is characterized by a small penis without penis duct behind the right tentacle (type a), and a short proximal vas 
Fig. 1 General scheme of imposex evolution in prosobranchs (adopted from Stroben et al. 1992a). Thick lines indicate imposex stages of B. areolata. ac aborted capsules, $c g$ capsule gland, $g p$ genital papilla, $o b c$ open bursa copulatrix, ocg open capsule gland, ocv occlusion of vulva, $p$ penis, $p d$ penis duct, $p r$ prostate gland, $t$ tentacle, $v d$ vas deferens, $v d p$ vas deferens passage into capsule gland, $v d s$ vas deferens section

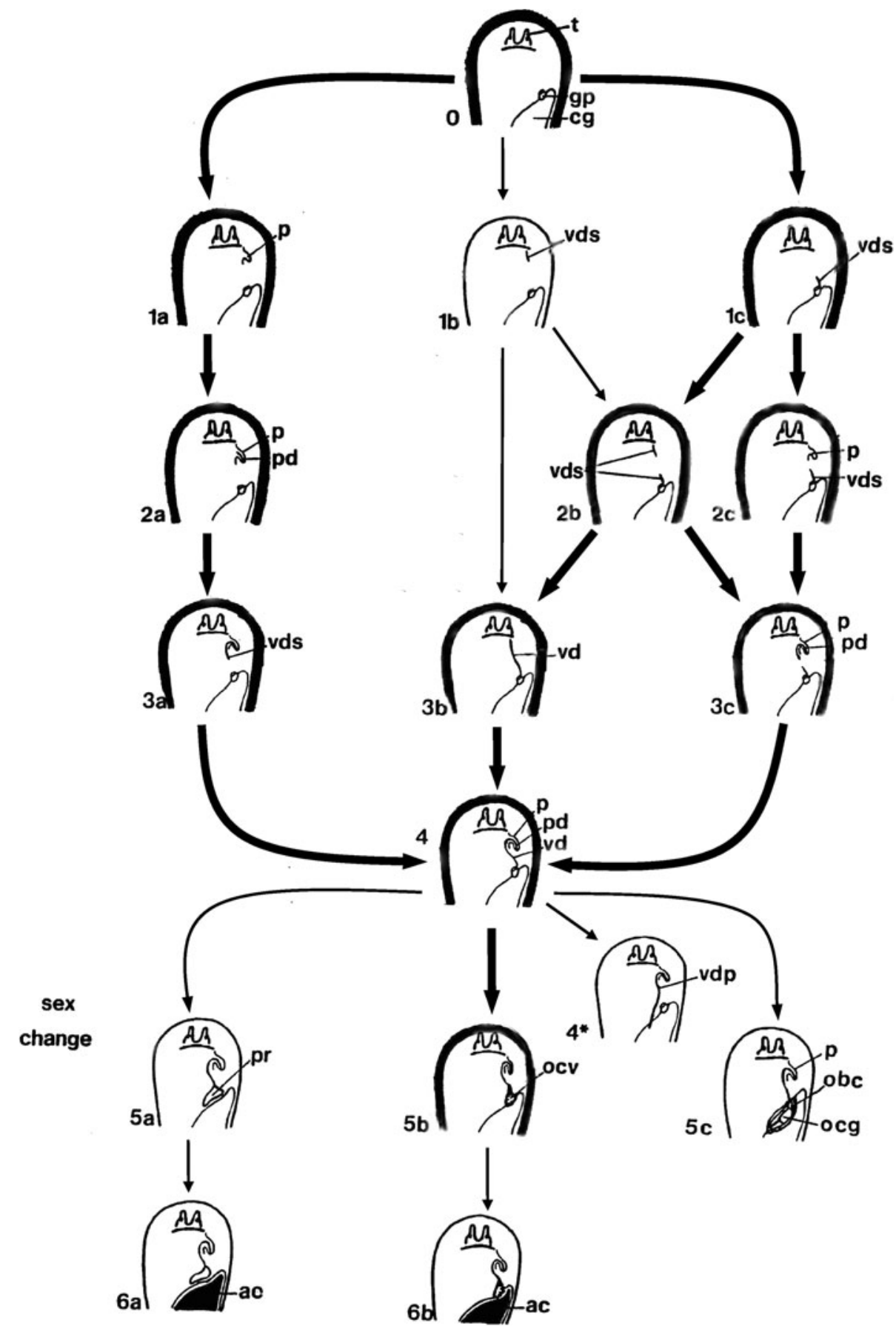

deferens section beginning at the vaginal opening (type c), to stage 4 that is characterized by a penis with duct and a vas deferens. In contrast to that of lower imposex stages (1-4), the vaginal opening of the females at stage 5 was occluded by the proliferating vas deferens tissue (type b).

\section{Imposex intensity}

All TBT concentrations used significantly induced imposex in females of $B$. areolata, whereas no imposex was observed in the control groups. After determining imposex intensity using the mean VDSI, it was shown that the stages of imposex observed ranged from 1 to 4 for the 1 and $50 \mathrm{ng}$ TBT as Sn/l, and the VDSI values recorded in females after exposure to these concentrations ranged from 1.0 to 1.7 and 1.0 to 2.3, respectively in all experimental months (Table 1). Furthermore, at the 10, 100 and $500 \mathrm{ng}$ TBT as $\mathrm{Sn} / \mathrm{l}$, the imposex stages found ranged from 1 to 5 , and the VDSI values recorded in females were in the ranges of 1.3-2.3, 1.2-2.6 and 1.2-3.0, respectively (Table 1). For 
Table 1 The vas deferens sequence index (VDSI) in female $B$. areolata during the 6 months of exposure to different nominal TBT concentrations

\begin{tabular}{|c|c|c|c|c|c|c|}
\hline \multirow{3}{*}{$\begin{array}{l}\text { TBT concentrations } \\
\text { (ng as } \mathrm{Sn} / \mathrm{l} \text { ) }\end{array}$} & \multicolumn{6}{|c|}{ Vas deferens sequence index (mean $\pm \mathrm{SE}$ ) } \\
\hline & \multicolumn{6}{|c|}{ Exposure time (months) } \\
\hline & 1 & 2 & 3 & 4 & 5 & 6 \\
\hline 0 (control) & 0 & 0 & 0 & 0 & 0 & 0 \\
\hline 1 & $1.0 \pm 0.2$ & $1.2 \pm 0.2$ & $1.4 \pm 0.3$ & $1.2 \pm 0.2$ & $1.7 \pm 0.7$ & $1.0 \pm 0.2$ \\
\hline 10 & $1.3 \pm 0.3$ & $1.4 \pm 0.4$ & $2.3 \pm 0.5$ & $1.9 \pm 0.4$ & $2.0 \pm 0.4$ & $1.8 \pm 0.4$ \\
\hline 50 & $1.0 \pm 0.2$ & $1.7 \pm 0.4$ & $1.9 \pm 0.4$ & $1.4 \pm 0.3$ & $2.3 \pm 0.4$ & $1.5 \pm 0.3$ \\
\hline 100 & $1.2 \pm 0.2$ & $1.8 \pm 0.4$ & $1.8 \pm 0.3$ & $2.2 \pm 0.3$ & $2.6 \pm 0.4$ & $2.1 \pm 0.3$ \\
\hline 500 & $1.2 \pm 0.2$ & $1.7 \pm 0.3$ & $2.0 \pm 0.3$ & $2.2 \pm 0.4$ & $2.4 \pm 0.3$ & $3.0 \pm 0.3$ \\
\hline
\end{tabular}

Table 2 The female penis length (FPL) (mm) in female B. areolata during the 6 months of exposure to different nominal TBT concentrations

\begin{tabular}{|c|c|c|c|c|c|c|}
\hline \multirow{3}{*}{$\begin{array}{l}\text { TBT } \\
\text { concentrations } \\
\text { (ng as } \mathrm{Sn} / \mathrm{l} \text { ) }\end{array}$} & \multicolumn{6}{|c|}{ Female penis length $(\mathrm{mm})($ mean $\pm \mathrm{SE})$} \\
\hline & \multicolumn{6}{|c|}{ Exposure time (months) } \\
\hline & 1 & 2 & 3 & 4 & 5 & 6 \\
\hline 0 (control) & 0 & 0 & 0 & 0 & 0 & 0 \\
\hline 1 & 0 & 0 & 0 & 0 & 0 & 0 \\
\hline 10 & 0 & $1.7 \pm 0.2$ & $3.8 \pm 0.4$ & $3.6 \pm 0.8$ & $3.4 \pm 0.9$ & $3.3 \pm 0.6$ \\
\hline 50 & 0 & 0 & $3.0 \pm 0.4$ & $2.7 \pm 0.2$ & $4.1 \pm 0.1$ & $2.7 \pm 0.2$ \\
\hline 100 & 0 & $2.2 \pm 0.2$ & $3.3 \pm 0.8$ & $4.1 \pm 0.5$ & $3.6 \pm 0.9$ & $3.3 \pm 0.5$ \\
\hline 500 & 0 & $4.2 \pm 0.6$ & $6.0 \pm 0.6$ & $5.4 \pm 0.5$ & $4.8 \pm 0.2$ & $4.6 \pm 0.2$ \\
\hline
\end{tabular}

the pooled data, all VDSI values for B. areolata were never higher than 3 .

In all TBT concentrations, imposex females started to develop their penis in the 2nd-3rd months of exposure (except that of the $1 \mathrm{ng}$ TBT as $\mathrm{Sn} / \mathrm{l}$, in which the penis was not formed) (Table 2). Comparing the FPL among the treatments, the results clearly showed that in all experimental months, most FPL values recorded for the low and medium TBT concentrations (10,50 and $100 \mathrm{ng}$ as $\mathrm{Sn} / \mathrm{l})$ were below $4.00 \mathrm{~mm}$ and ranged from 1.7 to $3.8,2.7$ to 4.1 and 2.2 to $4.1 \mathrm{~mm}$, respectively, whereas the FPL values recorded for the highest concentration (500 ng TBT as $\mathrm{Sn} / \mathrm{l}$ ) were in the range of $4.22-6.05 \mathrm{~mm}$ (Table 2) and close to those of the mean male penis length (MPL), in which most values were above $4.00 \mathrm{~mm}$ with the maximum value of $6.42 \mathrm{~mm}$ (data not shown).

\section{Ultrastructure of oogenesis in imposex females}

The ovaries of imposex female proceed through various developmental stages of oocytes within each ovarian acinus in a similar way to those of normal females. Based on the changes in size and cytoplasmic contents of oocytes, the present study distinguishes five stages of oocyte development in imposex females of $B$. areolata. Although the ultrastructural features of oogenesis in imposex females are generally normal, a notable histopathological disorder is present as documented in the following details:

\section{Pre-vitellogenic oocytes and follicle cells}

At the beginning of oogenesis, the primary oogonia (about $24.1 \mu \mathrm{m}$ in diameter) divide to form secondary oogonia that enter into their first meiotic division and become primary oocytes (pre-vitellogenic oocytes). At this stage, the oocytes are approximately $50 \mu \mathrm{m}$ in diameter and are more elongated than the oogonia. Early pre-vitellogenic oocytes possess a large, round nucleus (about $23 \mu \mathrm{m}$ in diameter) with scattered heterochromatin and a prominent electrondense nucleolus. As the oocytes grow larger, the nucleus develops two nucleoli (Fig. 2a), and in the cytoplasm adjacent to the nuclear membrane, patches of nuage-like material exhibit tightly clustered fine granules that are surrounded by small, round mitochondria with prominent cristae (Fig. 2b).

Follicle cells are associated with all stages of oocytes particularly with the oogonia and pre-vitellogenic oocytes and often completely surround them. In both normal and imposex females, follicle cells (about $16 \mu \mathrm{m}$ diameter) possess spherical to irregularly shaped nuclei containing scattered patches of dense heterochromatin and a prominent nucleolus (Fig. 2c, d). The cytoplasm contains numerous extensive, parallel arrays of RER cisternae, Golgi bodies and tubular mitochondria (Fig. 2c-f). In imposex females, large lipid droplets (about $1.3 \mu \mathrm{m}$ in diameter) are abundant in the cytoplasm of the follicle cells (Fig. 2c), whereas this structure is not obvious in the 
Fig. 2 Pre-vitellogenic oocytes (PVO) and follicle cells $(F C)$ of $B$. areolata. a Nucleus $(N)$ of imposex female PVO with a large amphinucleolus $(A N)$ and a small eunucleolus $(E N)$. b The patches of nuage-like material (arrowheads) in the perinuclear ooplasm of imposex female PVO. c FC of imposex female. d FC of normal female. e FC of imposex female showing well developed Golgi body $(G)$. f The round mitochondria with loosed cristae (asterisks) and tubular mitochondria with bipartition (arrowheads) in FC of normal female. $d b$ dense body, $G V$ Golgi vesicle, $L$ lipid droplets, $M$ mitochondria, $\mathrm{Nu}$ nucleolus, RER rough endoplasmic reticulum. Scale bar $=2 \mu \mathrm{m}$
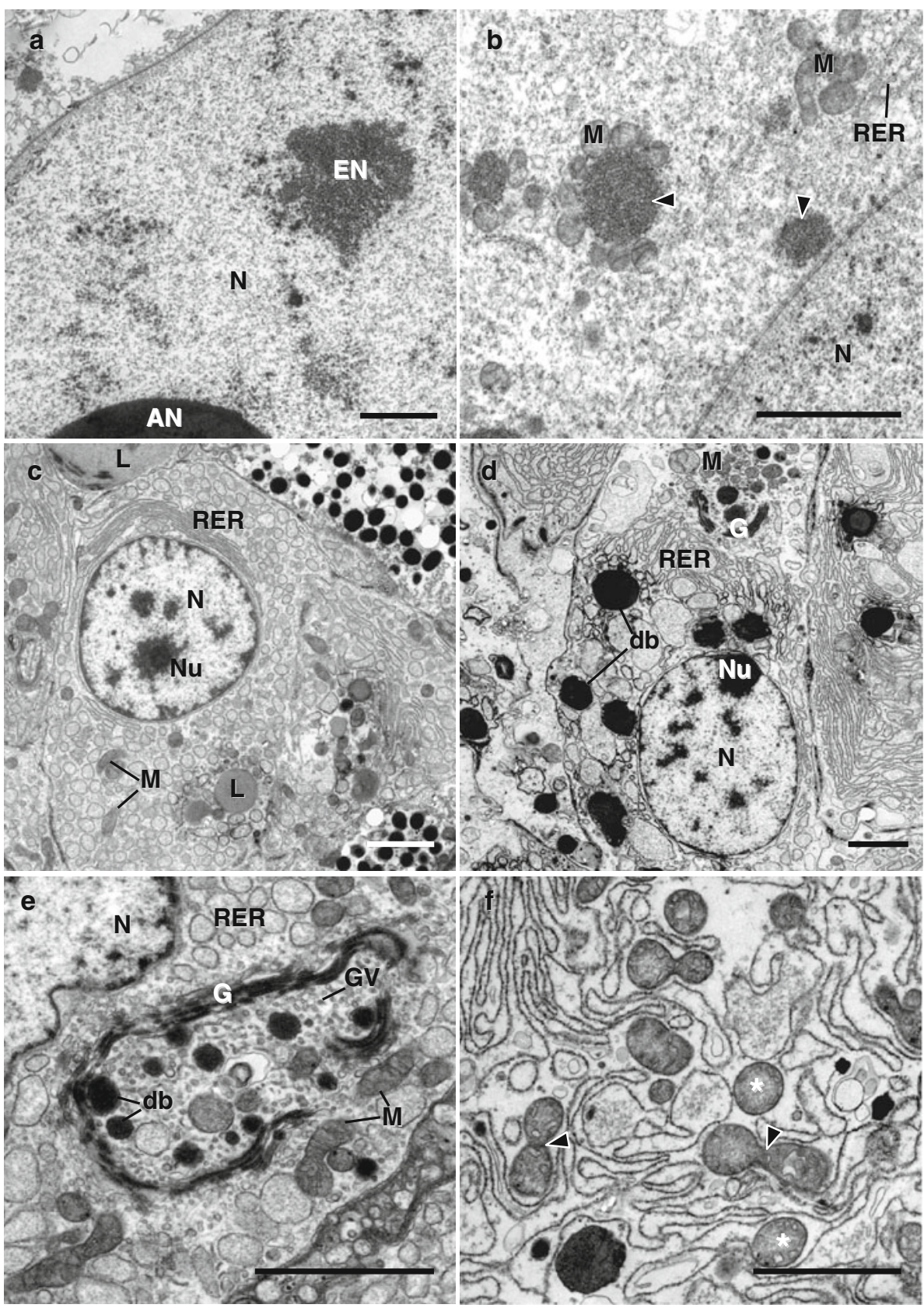

normal females (Fig. 2d). A characteristic feature of the follicle cells is the well-developed Golgi bodies that produce numerous small, spherical vesicles. These form larger homogenous, electron-dense bodies $(0.6 \mu \mathrm{m}$ diameter $)$ (Fig. 2e). At the same time, many elongated mitochondria divide by bipartition and some loose their cristae to become small, round vesicles (Fig. 2f).

\section{Early vitellogenic oocytes}

The early vitellogenic oocytes of both imposex and normal female attain a size of approximately $60 \mu \mathrm{m}$ in diameter.
Their prominent, enlarged germinal vesicles are round to oval, contain an electron-dense nucleolus in which an electron-lucent space is clearly visible (Fig. 3a). Patches of nuage-like material with fine granules are in close contact with the nuclear envelope. They are surrounded by small, round mitochondria (Fig. 3b). At this stage of development, the amount of ooplasm and the number of ooplasmic organelles including the ribosomes, the mitochondria, the RER and the Golgi bodies increase (Fig. 3c-e).

The most remarkable feature of the early vitellogenic oocytes is the synthesis of at least 3 types of ooplasmic inclusions, including membrane-bound electron-lucent 
Fig. 3 Early vitellogenic oocyte $(E V O)$ of $B$. areolata. a Nucleus $(N)$ of imposex female EVO with a nucleolus $\mathrm{Nu}$ ) containing electron-lucent space $(E S)$. b EVO of imposex female showing nuage-like material (asterisk) surrounded by mitochondria that divide by bipartition (arrowhead). c Ooplasm of imposex female EVO. d Ooplasm of normal female EVO. e Golgi body $(G)$ of imposex female. $\mathbf{f}$ The annulate lamellae (asterisk) in the ooplasm of imposex female EVO. $C G$ cortical granule, $G V$ Golgi vesicle, $L$ lipid droplet, $M$ mitochondria, $V$ electron-lucent vesicle, $Y$ yolk body. Scale bars $=0.5 \mu \mathrm{m}(\mathbf{b}, \mathbf{e}, \mathbf{f})$ and $2 \mu \mathrm{m}(\mathbf{a}, \mathbf{c}, \mathbf{d})$
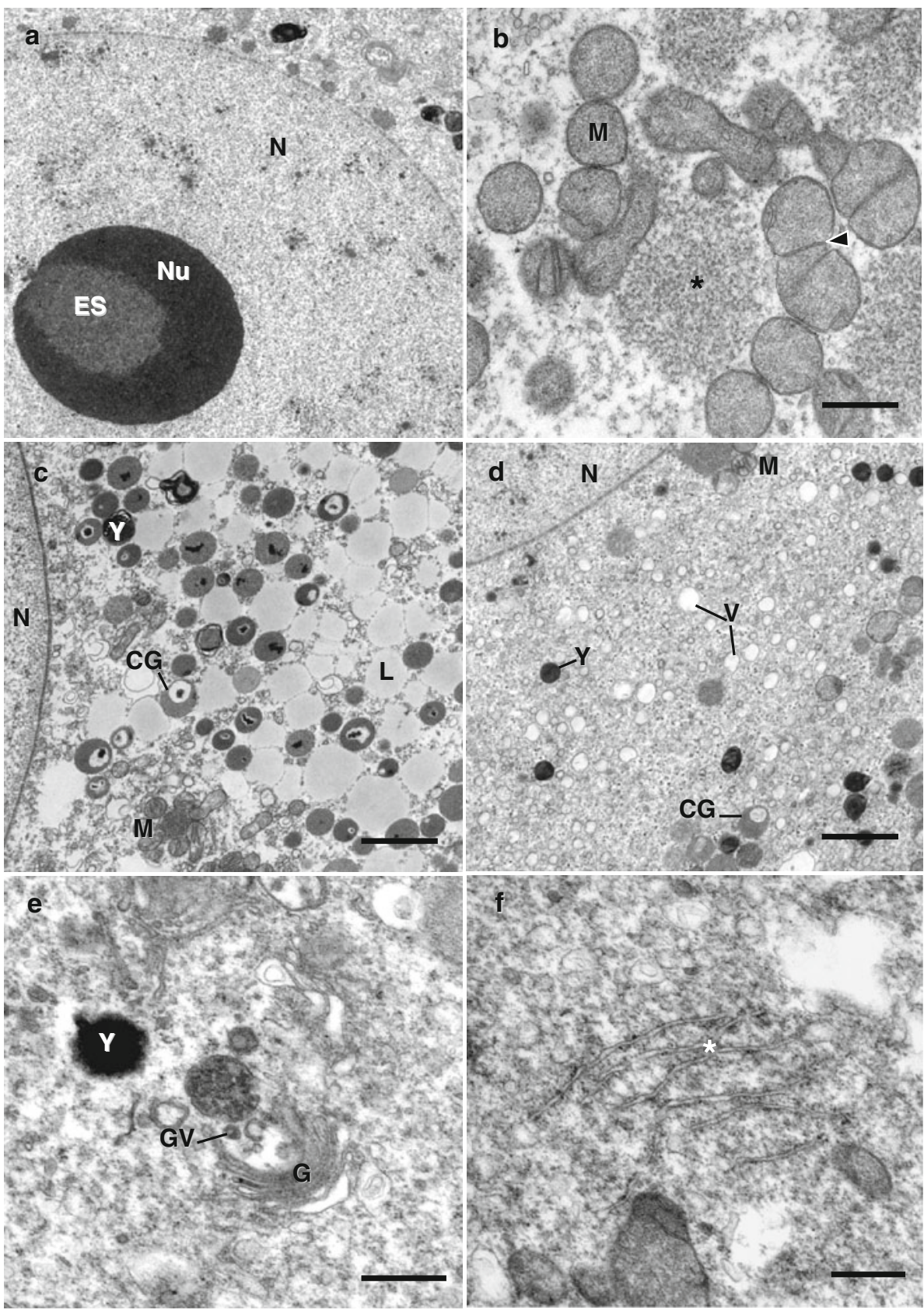

vesicles, yolk bodies and cortical granules that are loosely dispersed throughout the ooplasm and start to increase in their numbers during this stage (Fig. 3c, d). It is interesting to note that numerous large lipid droplets ( $1 \mu \mathrm{m}$ diameter) are found in the ooplasm of the imposex females (Fig. 3c), whereas in the normal female, lipid droplets are not evident (Fig. 3d). In both groups, the synthesis of the yolk body starts when the maturing face of the Golgi bodies produces small vesicles which then fuse to form a homogenous, electron-dense yolk body (about $0.8 \mu \mathrm{m}$ in diameter) (Fig. 3e). The lamellar structures observed during vitellogenesis are annulate lamellae that are found in clusters (Fig. 3f).

\section{Late vitellogenic oocytes}

The late vitellogenic oocytes of imposex and normal females are similar in their structures. These oocytes are about $105 \mu \mathrm{m}$ in diameter and larger than the early vitellogenic oocytes. A round germinal vesicle occupying a large volume of the ooplasm contains a spherical, electrondense nucleolus in the nucleoplasm (Fig. 4a). In the perinuclear region, patches of nuage-like material with fine granules still persist at this stage and are often surrounded by small, round mitochondria (Fig. 4b). Oocyte lipid droplets, electron-lucent vesicles, yolk bodies and cortical granules fill the ooplasm in a similar way to those seen at 
Fig. 4 Late vitellogenic oocytes (LVO) of B. areolata. a LVO of normal female. b Nuage-like material (asterisk) surrounded by mitochondria $(M)$ in LVO of normal female. c Ooplasm of LVO of normal female. d Ooplasm of LVO of imposex female showing many large lipid droplets $(L)$. $C G$ cortical granule, $N$ nucleus, $\mathrm{Nu}$ nucleolus, $\mathrm{V}$ electron-lucent vesicle, $Y$ yolk body. Scale bars $=0.5 \mu \mathrm{m}(\mathbf{b}), 1 \mu \mathrm{m}$ (d) and $2 \mu \mathrm{m}(\mathbf{a}, \mathbf{c})$

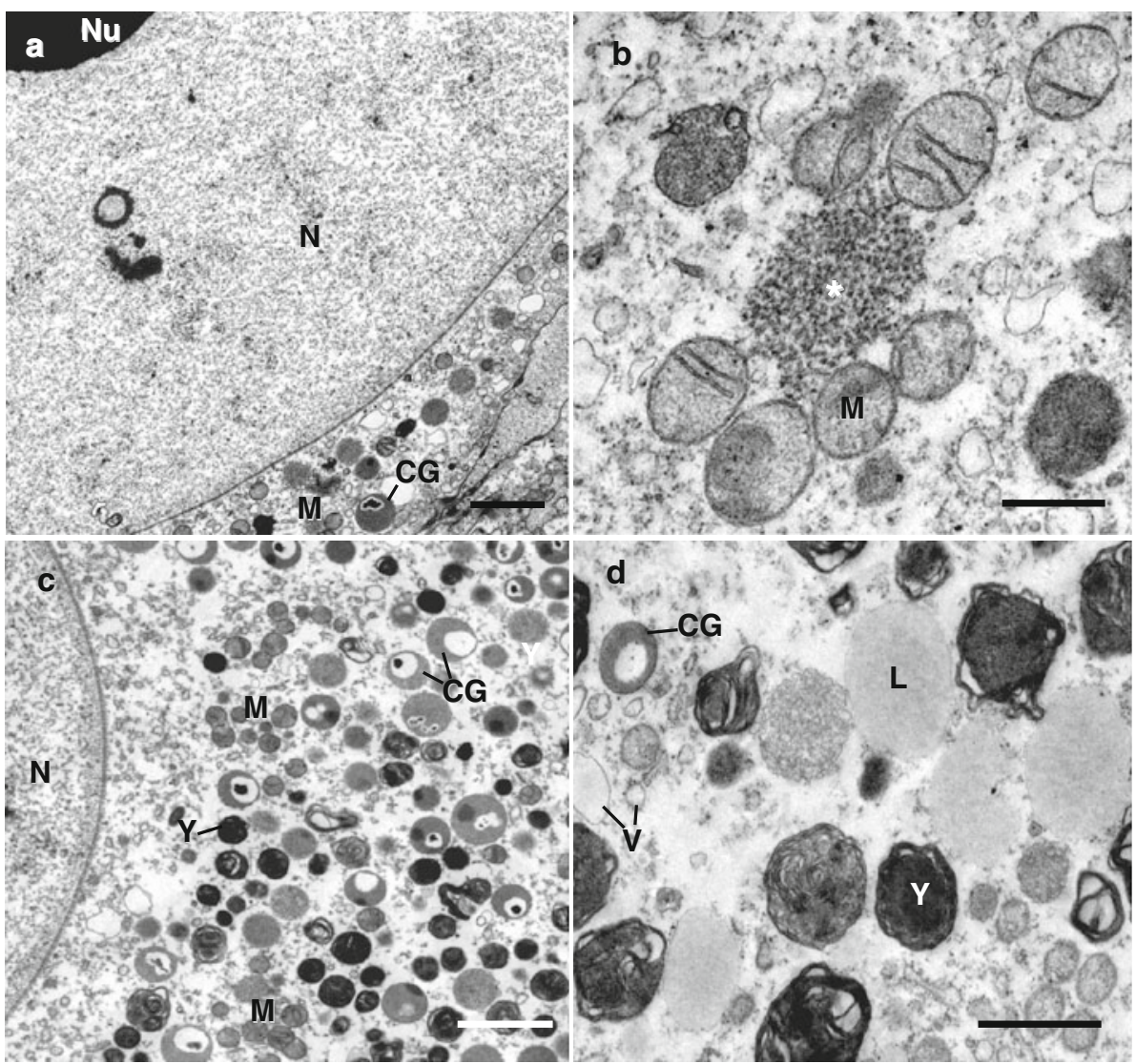

the early vitellogenic stage, but they appear in larger numbers (Fig. 4c, d). Large lipid droplets with no limiting membrane are observed in a similar way to those of the early vitellogenic oocytes but only in the imposex females (Fig. 4d), and not in the normal females (Fig. 4c). The membrane-bound, spherical bodies $(1.1 \mu \mathrm{m}$ diameter $)$, cortical granules, are less electron dense than the yolk bodies and show both dark and light regions (Fig. 4a, c, d).

As vitellogenesis proceeds, numerous elements of the Golgi bodies in the ooplasm are involved in the process of yolk formation. This process is initiated by the production of numerous, small Golgi vesicles, containing electrondense material. Later, they fuse to form growing yolk bodies. In addition, Golgi bodies may also produce the electron-lucent vesicles $(0.7 \mu \mathrm{m}$ diameter $)$ that are positioned near to the Golgi regions and are dispersed throughout the ooplasm (Fig. 5a). At the same time, some Golgi bodies form elaborate whorls and stacks around their vesicles (Fig. 5b). These structures become more dense (Fig. 5c) and fuse to form the growing yolk bodies of heterogeneous appearance that originate from the fusion of two or three whorls inside (Fig. 5d). Another way in which the yolk bodies are formed is by surrounding the young yolk bodies with homogenous electron-dense, pre-yolk material (Fig. 5e). The multi-vesicular bodies develop considerably and often encompass several small, young yolk bodies (Fig. 5e insert). These become the core of a single, larger maturing yolk body (Fig. 5f). The external envelope of the yolk bodies is formed by numerous membranes surrounding the core (Fig. $5 \mathrm{~g}$ ). Several of these membranes fuse. Finally, the mature yolk body $(2.3 \mu \mathrm{m}$ in diameter) is formed and shows a typical central, electrondense core surrounded by a clear membranous envelope (Fig. 5h).

As vitellogenesis progresses, endocytotic activity is seen along the oolemma in the form of pits (Fig. 5i). An invagination of these pits occurs; they are then internalized into the cortical ooplasm to form a coated vesicle or endosome (Fig. 5i, j). The spherical or irregularly shaped endosomes fuse and coalesce their contents gradually transform into homogenous, electron-dense yolk bodies (Fig. 5j).

\section{Mature oocytes}

Mature oocytes are the largest germinal cells. In both the imposex and normal females, oocytes of about $186 \mu \mathrm{m}$ in diameter possess a very large germinal vesicle that displays irregular outlines and dispersed chromatin. The round 
Fig. 5 Late vitellogenic oocytes $(L V O)$ of $B$. areolata. a LVO of normal female showing Golgi body $(G)$ and abundant electron-lucent vesicles $(V)$. b Golgi body of LVO of imposex female beginning to encompass its vesicles. c Dense structure (asterisk) in LVO of imposex female. d Many fused whorls (asterisks) in LVO of imposex female. e Pre-yolk materials in a form of curly-shaped membranes (asterisk) surrounding the yolk body $(Y)$. Insert: multi-vesicular body (arrowhead). f The electrondense core of yolk body. $\mathbf{g}$ The fused membrane (asterisk) surrounding the core. $\mathbf{h}$ The mature yolk body with a clear envelope (asterisk).

i Endocytotic pits (arrowheads) and endosomes (arrows). j Irregularly shaped endosomes (arrowheads). CG cortical granule, $G V$ Golgi vesicle, $M$ mitochondria, $N$ nucleus. Scale bars $=0.5 \mu \mathrm{m}(\mathbf{j}), 1 \mu \mathrm{m}$ $(\mathbf{a}-\mathbf{f}, \mathbf{i}$, Insert $)$ and $2 \mu \mathrm{m}(\mathbf{g}-\mathbf{h})$

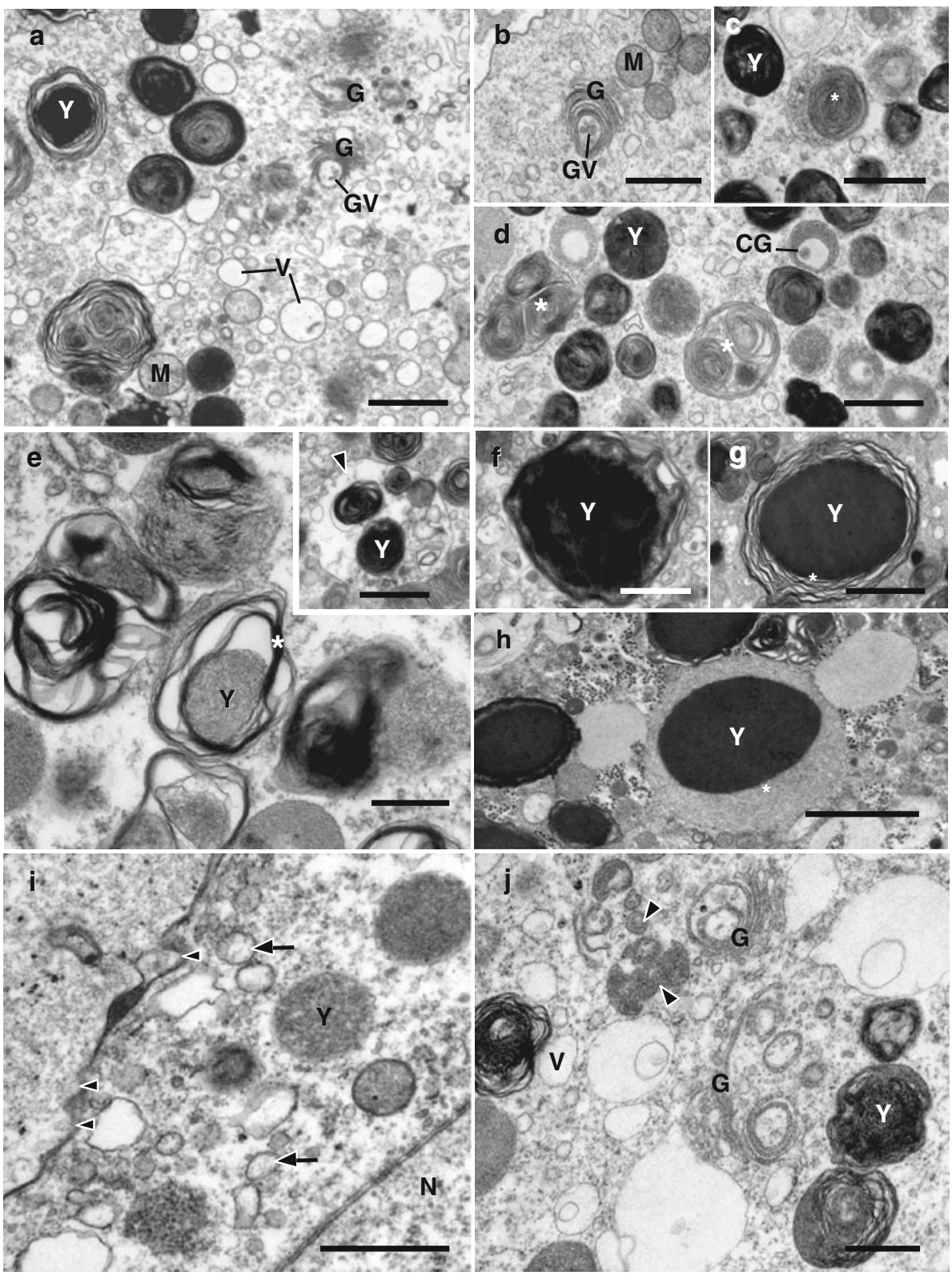

nucleolus is electron dense with clearly defined light areas within it (Fig. 6a). The ooplasm contains numerous small, round mitochondria, yolk bodies, cortical granules and electron-lucent vesicles. Many elements of the Golgi bodies appear to synthesize the yolk bodies that measure up to $4 \mu \mathrm{m}$ in diameter (Fig. 6b). At this stage, exocytotic vesicles resembling electron-lucent vesicles are commonly found in the cortical ooplasm where they may be involved in the process of releasing material into the perivitelline space (Fig. 6c, d). Mature oocytes are surrounded by a vitelline envelope that consists of evenly spaced parallel microvilli penetrating an extracellular matrix or vitelline layer (Fig. 6d).

\section{Discussion}

Based on VDSI, the finding of low to moderate intensity of imposex in $B$. areolata (all VDSI values $\leq 3$ ) indicated a low TBT sensitivity for this species that is similar to other buccinid species (Stroben et al. 1992b). In addition, earlier surveys of imposex in gastropods of the Buccinidae (Stroben et al. 1992b; Oehlmann et al. 1998) suggested that imposex development in this family would not be likely to lead to female sterility because the final point of imposex is always not higher than stage 4 . However, the presence of sterilized females at stage 5 of $B$. areolata indicates that within the Buccinidae this species is less tolerate to TBT 
Fig. 6 Mature oocyte $(M O)$ of B. areolata. a $\mathrm{MO}$ of the normal female. b Ooplasm of the MO of the imposex female. $\mathbf{c}$ The cortical ooplasm of the MO of the normal female. Note the exocytotic vesicles (arrows) and the outfolding of the ooplasmic membrane (arrowhead) before forming microvilli. d The periphery of the MO of the normal female showing microvilli (asterisk) and exocytotic vesicles (arrows). $C G$ cortical granule, $G$ Golgi body, $M$ mitochondria,

$\mathrm{N}$ nucleus, $\mathrm{Nu}$ nucleolus, $V$ electron-lucent vesicle, $Y$ yolk body.

Scale bars $=0.4 \mu \mathrm{m}(\mathbf{c})$, $0.8 \mu \mathrm{m}(\mathbf{d}), 1 \mu \mathrm{m}(\mathbf{b})$ and $2 \mu \mathrm{m}(\mathbf{a})$
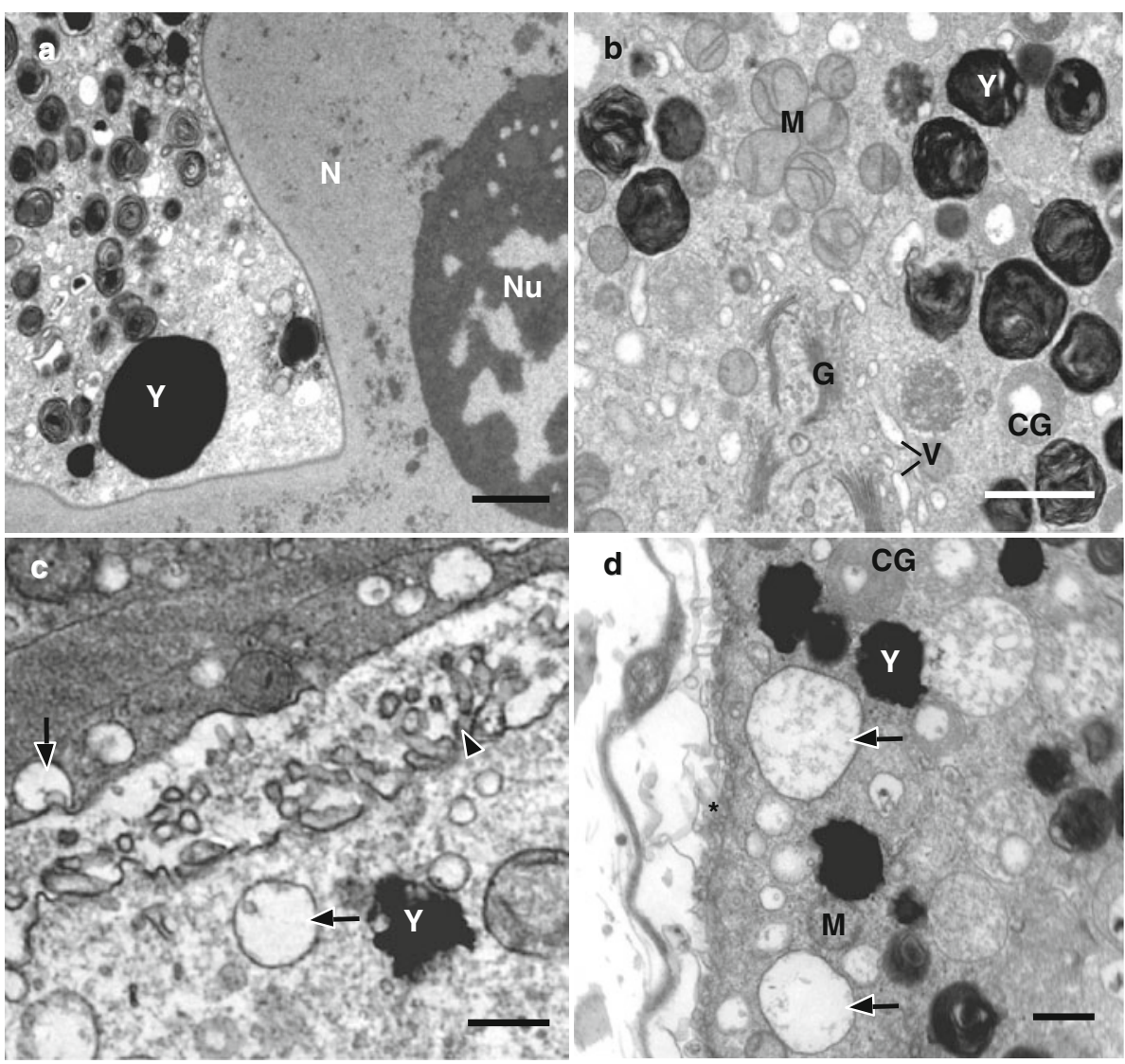

than others. Thus, further studies of imposex should be explored for other species in the Buccinidae.

At the light microscopic level, the ovaries of $B$. areolata at lower imposex stages, at least up to stage 4 , exhibited the normal histological structures as pure females (stage 0 ) (unpublished results); this is in line with the observations in other prosobranchs, e.g. Ocinebrina aciculata (Oehlmann et al. 1996), Bolinus brandaris (Ramon and Amor 2001) Buccinum undatum (Mensink et al. 2002) and Thais rufotincta (Cheng and Liu 2004). In contrast, previous studies have demonstrated that imposex females induced by TBT - after a severe spill incident (at the stages 5 and 6) may exhibit two unnatural conditions: a suppression or impairment of oogenesis and a development of spermatogenesis in the ovary (Oehlmann et al. 1996; Axiak et al. 2003; Horiguchi et al. 2006). In the present study, ultrastructural evidence undoubtedly showed that no male tissue developed in any imposex females at stage 5 of $B$. areolata. This is in contrast to $H$. trunculus where ovarian spermatogenesis was found in the most advanced imposex stage (Axiak et al. 2003). Indeed, the ovarian spermatogenesis in B. areolata might occur at higher environmental TBT concentrations and durations of exposure. In addition, oogenesis in the imposex female B. areolata was similar to that of the normal female, indicating that an alteration of this process at the ultrastructural level did not occur such as has been previously observed in Bolinus brandaris (Amor et al. 2004). However, the presence of numerous lipid droplets in the cytoplasm at almost all stages of the oocytes development and of the follicle cells in imposex female B. areolata may imply a sign of oocyte degeneration that could finally lead to the suppression of oogenesis, and this was similar to those found in imposex females of $\mathrm{H}$. trunculus (Axiak et al. 2003). In these cases, TBT is thought to be a causative agent for this histopathological disorder through a shift in energy balance from reproduction to detoxicification (Axiak et al. 2003).

Vitellogenesis in the oocytes of $B$. areolata involves both autosynthetic and heterosynthetic processes, whereas many species in the caenogastropods such as the nassariid I. obsoleta (Taylor and Anderson 1969), muricid B. brandaris (Amor et al. 2004) and buccinid Neptunea (barbitonia) arthritica cumingii (Chung et al. 2006) formed their yolk bodies only by autosynthesis. In $B$. areolata, this process is involved with the combined activities among proteosynthetic organelles including RER and Golgi bodies. As vitellogenesis proceeds in B. areolata, the production of yolk bodies via autosynthesis is sometimes complemented by multivesicular bodies, similar to those in I. obsoleta (Gerin 1976) and N. arthritica cumingii (Chung et al. 2006); unfortunately, it is not possible to determine how the multivesicular bodies originate. However in most 
gastropods, their yolk formation via heterosynthesis involving endocytosis is less widespread than that produced by autosynthesis, and this seems to be confined to some caenogastropods like the buccinid C. stimpsoni (West 1981) and the neritid Bathynerita naticoidea (Eckelbarger and Young 1997), the patellogastropods, Patella spp. and Helcion pectunculus (Hodgson and Eckelbarger 2000) as well as the pulmonate, Siphonaria serrata ( $\mathrm{Pal}$ and Hodgson 2002). In B. areolata, endocytotic activity is detected by the presence of endocytotic pits and vesicles that gradually fuse to form yolk bodies. The appearance of these pits probably indicates the uptake of extra-ovarian substances, but their origin has still to be identified.

The mature yolk bodies of $B$. areolata are similar to those found in B. brandaris (Amor et al. 2004) and N. arthritica cumingii (Chung et al. 2006), as they exhibit an electrondense core surrounded by a clear envelope. In addition, the cortical granules in B. areolata was present in the vitellogenic oocytes as has been described for the primitive gastropods such as Patella spp. and H. pectunculus (Hodgson and Eckelbarger 2000), and Haliotis varia (Najmudeen 2008). In contrast, this structure was not found in B. naticoidea (Eckelbarger and Young 1997), B. brandaris (Amor et al. 2004) and N. arthritica cumingii (Chung et al. 2006). The mature oocytes of $B$. areolata develop microvilli similar to those found in Patella spp. and H. pectunculus (Hodgson and Eckelbarger 2000) and H. varia (Najmudeen 2008). Apart from forming junctions with adjacent oocytes, microvilli help in absorption, transportation and secretion of egg envelopes (Norrevang 1968; Wourms 1987). It is interesting to note, however, that not all gastropod oocytes have microvilli, e.g. B. naticoidea (Eckelbarger and Young 1997) and N. arthritica cumingii (Chung et al. 2006). Exocytosis of material into the perivitelline space has been observed in bivalves (Pipe 1987; Eckelbarger and Young 1999). For the buccinid B. areolata, this is the first report of such a process and it should be further investigated.

In conclusion, this investigation provides evidence for the similarities in the ultrastructure of oogenesis between imposex and normal females of $B$. areolata. However, imposex females demonstrate oocyte degeneration as indicated by the presence of numerous lipid droplets in their ovarian tissues. In addition, vitellogenesis in $B$. areolata is generally consistent with that of prosobranchs and is also related to that of pulmonates in having both auto- and heterosynthetic processes. In particular, the appearance of cortical granules in the ooplasm and microvilli on the vitelline envelope seem to be the unique features of $B$. areolata that differ from other gastropods in the Buccinidae.

Acknowledgments This work was in part funded by a grant from the Thailand Research Fund through the Royal Golden Jubilee PhD Program (grant no. PHD/0076/2547), the Graduate School and research fund of Prince of Songkla University, Thailand. The Aquatic Animal Hatchery and Research Unit, Prince of Songkla University is acknowledged for providing specimens. Many thanks to the TEM staff of the Core Facility Cell Imaging and Ultrastructure Research, Faculty of Life Science, University of Vienna for their technical assistance.

\section{References}

Altena CO, Van Regteren Gittenberger E (1981) Zoologische Verhandelingen, vol 188. E-J Brill, Leiden, pp 1-57

Amor MJ, Ramón M, Durfort M (2004) Ultrastructural studies of oogenesis in Bolinus brandaris (Gastropoda: Muricidae). Sci Mar 68(3):343-353

Axiak V, Micallef D, Muscat J, Vella A, Mintoff B (2003) Imposex as a biomonitoring tool for marine pollution by tributyltin: some further observations. Environ Int 28(8):743-749

Cheng CY, Liu LL (2004) Gametogenesis in the imposex-affected oyster drills, Thais clavigera and Thais rufotincta. J Fish Soc Taiwan 31:55-65

Chung E, Kim SY, Park G (2006) Germ cell differentiation and sexual maturation of the female Neptunea (barbitonia) arthritica cumingii (Crosse, 1862) (Gastropoda: Buccinidae). Malacologia 48(1-2):65-76

deFur PL, Crane M, Ingersoll C, Tattersfield L (eds) (1999) Endocrine disruption in invertebrates: endocrinology, testing, and assessment. Proceedings of the Workshops on Endocrine Disruption in Invertebrates, 12-15 December 1998, Noordwijkerhout, The Netherlands. SETAC Press, Pensa cola

Eckelbarger KJ, Young CM (1997) Ultrastructure of the ovary and oogenesis in the methane-seep mollusc Bathynerita naticoidea (Gastropoda: Neritidae) from the Louisiana slope. Invertebr Biol 116:299-312

Eckelbarger KJ, Young CM (1999) Ultrastructure of gametogenesis in a chemosynthetic mytilid bivalve (Bathynerita childresi) from a bathyal, methane seep environment (Northern Gulf of Mexico). Mar Biol 135:635-646

Gerin Y (1976) Origin and evolution of some organelles during oogenesis in the mud snail Ilyanassa obsoleta. I. The yolk platelets. Acta Embryol Exp 1:15-26

Gibbs PE, Pascoe PL, Burt GR (1988) Sex change in the female dogwhelk, Nucella lapillus, induced by tributyltin from antifouling paints. J Mar Biol Assoc UK 68(4):715-731

Harino H, Ohji M, Wattayakorn G, Arai T, Rungsupa S, Miyazaki N (2006) Occurrence of antifouling biocides in sediment and green mussels from Thailand. Arch Environ Contam Toxicol 51:400-407

Hodgson AN, Eckelbarger KJ (2000) Ultrastructure of the ovary and oogenesis in six species of patellid limpets (Gastropoda: Petellogastropoda). Invertebr Biol 119(3):265-277

Horiguchi T, Kojima M, Kaya M, Matsuo T, Shiraishi H, Morita M, Adachi Y (2002) Tributyltin and triphenyltin induce spermatogenesis in ovary of female abalone, Haliotis gigantean. Mar Environ Res 54(3-5):679-684

Horiguchi T, Kojima M, Hamada F, Kajikawa A, Shiraishi H, Morita M, Makoto Shimizu (2006) Impact of tributyltin and triphenyltin on ivory shell (Babylonia japonica) populations. Environ Health Perspect 114(S-1):13-19

Kan-Atireklap S, Tanabe S, Sanguansin J (1997) Contamination by butyltin compounds in sediments from Thailand. Mar Pollut Bull 34(11):894-899

Kritsanapuntu S, Chaitanawisuti N, Natsukari Y (2007) Effects of different diets and seawater systems on egg production and 
quality of the broodstock Babylonia areolata L. under hatchery conditions. Aquac Res 38:1311-1316

Kritsanapuntu S, Chaitanawisuti N, Natsukari Y (2009) Growth and water quality for growing-out of juvenile spotted Babylon, Babylonia areolata, at different water exchange regimes in a large-scale operation of earthen ponds. Aquac Int 17:77-84

Mensink BP, Kralt H, Vethaak AD, Hallers-Tjabbes CCT, Koeman JH, Van Hattum B, Boon JP (2002) Imposex induction in laboratory reared juvenile Buccinum undatum by tributyltin (TBT). Environ Toxicol Pharmacol 11(1):49-65

Najmudeen TM (2008) Ultrastructeral studies of oogenesis in the variable abalone Haliotis varia (vetigastropoda: Haliotidae). Aquat Biol 2:143-151

Norrevang A (1968) Electron microscopic morphology of oogenesis. Int Rev Cytol 23:113-186

Oehlmann J, Fioroni P, Stroben E, Markert B (1996) Tributyltin (TBT) effects on Ocinebrina aciculata (Gastropoda: Muricidae): Imposex development, sterilization, sex change and population decline. Sci Total Environ 188(2-3):205-223

Oehlmann J, Stroben E, Schulte-Oehlmann U, Bauer B (1998) Imposex development in response to TBT pollution in Hinia incrassata (Strom, 1768) (Prosobranchia, Stenoglossa). Aquat Toxicol 43(4):239-260

Pal P, Hodgson AN (2002) An ultrastructeral study of oogenesis in a planktonic and a direct-development species of Siphonaria (Gastropoda: Pulmonata). J Mollus Stud 68:334-337

Pipe RK (1987) Oogenesis in the marine mussel Mytilus edulis: an ultrastructural study. Mar Biol 95:405-414

Ramon M, Amor MJ (2001) Increasing imposex in populations of Bolinus brandaris (Gastropoda: Muricidae) in the north-western Mediterranean. Mar Environ Res 52(5):463-475

Smith BS (1971) Sexuality in the American mud snail, Nassarius obsoletus Say. In: Proceedings of the malacological society of London, vol 39, pp 337-378
Stroben E, Brommel C, Oehlmann J, Fioroni P (1992a) The genital systems of Trivia arctica and T. monacha (Prosobranchia: Mesogastropoda) and tributyltin induced imposex. Zool Beitr Neu Fol 34(3):349-374

Stroben E, Oehlmann J, Fioroni P (1992b) The morphological expression of imposex in Hinia reticulata (Gastropoda: Buccinidae): a potential biological indicator of tributyltin pollution. Mar Biol 113:625-636

Supanopas P, Sretarugsa P, Kruatrachue M, Pokethitiyook P, Upatham ES (2005) Acute and subchronic toxicity of lead to the spotted Babylon, Babylonia areolata (Neogastropoda, Buccinidae). J Shellfish Res 24:91-98

Suwanjarat J, Muenpo C, Thoungboon L (2008) Reproductive cycle of Babylonia areolata in the Gulf of Thailand. Thaksin J 11(2):71-86 (In Thai)

Swennen C, Ruttanadakul N, Ardseungnern S, Singh HR, Mensink BP, Ten Hallers-Tjabbes CC (1997) Imposex in sublittoral and littoral gastropods from the Gulf of Thailand and Strait of Malacca in relation to shipping. Environ Tech 18(12):1245-1254

Swennen C, Sampantarak U, Ruttanadakul N (2009) TBT-pollution in the Gulf of Thailand: a re-inspection of imposex incidence after 10 years. Mar Pollut Bull 58:526-532

Taylor GT, Anderson E (1969) Cytochemical and fine structural analysis of oogenesis in the gastropod Ilyanassa obsoleta. J Morphol 129:211-248

West DL (1981) Reproductive biology of Colus stimpsoni (Prosobranchia: Buccinidae). IV. Oogenesis. Veliger 24:28-38

Wourms JP (1987) Oogenesis. In: Giese AC, Pearse JS, Pearse VB (eds) Reproduction of marine invertebrates, vol 9. Blackwell, California, pp 50-178

Xu YB, Ke CH, Wang DX, Wei YJ, Lv JQ (2006) Studies on protein requirement of Babylonia areolata Lin. J Xiamen Univ $45: 216-220$ 